\title{
Insurance and Its Business in Nepal
}

\section{Jas Bahadur Gurung}

\begin{abstract}
This study aims mainly to analyze the performance of insurance business in Nepal. The data used in this study is mainly quantitative and analysis has been carried out by using simple percentage and correlation coefficient. The study reveals that there are altogether 25 insurance companies viz. 8 life insurance and 16 non-life insurance and one offer both life and non-life services. They have altogether 340 branch offices in Nepal. The growth of insurance policies for both life and non-life insurance companies has been increasing and significant during the study period. Similarly, the progressive trend of premium collection reached to 48 percent for non-life and 37.06 percent for life insurance in FY 2066/67 and contributed 1.70 percent in GDP of the economy. Moreover, the investment of insurance companies has been positive but fluctuating over the period under study. However, the correlation coefficient between total premium collection and total investment is positive with $r=0.97$ and significant as its $P E$ is only 0.0163. These facts reveal that the performance of insurance business in Nepal is satisfactory.
\end{abstract}

Keywords: insurance, life and non-life, premium and investment.

\section{Introduction}

Marine insurance was the first in the world history of insurance. Fire insurance was a later development. After fire insurance, life insurance came into existence. Conventionally, insurance was considered as a cooperative form of distributing a certain risk over a group of persons who are exposed to it. But now it is taken as a contract or an agreement in which it is agreed that a certain amount of money would be paid as compensation in case the loss or destruction occurs due to certain risks. In return, the insured agrees to pay a certain amount as premium.

People live in society. Society is full of risks and uncertainty. Insurance is a device providing financial compensation to those who suffer from misfortune. In other words, insurance is the best means for security to human life and property from various risks (Shrestha, 2001). It is a kind of investment, from which one gets return only when certain loss occurred from predetermined incidents (Singh, 2009). Moreover, life insurance encourages savings in the society because insured is paid back a lump sum amount with some bonus if he/she alive at the end of the period. 
From the economic point of view, insurance is a business through which the scattered savings are collected in the form of premium and become an important source of funds for capital investment. Generally insurance companies invest such funds typically in shipping centers, hospitals, factories, housing development, new plants, etc. (Singh, 2009). As such, insurance business creates capital fund and promotes development, growth and prosperity of a country. Furthermore, insurance companies are considered as an important part of institutional investment of any country as they invest in corporate securities as well as other collective investment schemes and in turn, they produce sufficient income to meet their obligations in the form of promised insurance benefits (SEBON, 2007). In Nepal, insurance business is regulated by Insurance Board (Beema Samiti).

This study is basically focused on the analysis of premium collection and investment as well as insurance companies, insurance policies and insurance agents in Nepalese perspective.

\section{Literature Review}

After the enactment of new Insurance Act in 2049, number of insurance companies has been established this was considered as the golden period in the insurance business history of Nepal. A number of modern insurance companies were established from private sectors contributing a lot in the economic growth of the country (Singh, 2005).

Thapa and Neupane (2056 BS) argued that the insurance business started to flourish in Nepal because many industries were established and the people really became aware of the businesses. As a result, many people were involved in it which ultimately contributed to the national development. They found that there were around 19 insurance companies (both life and non-life) working in Nepal.

Insurance companies collect the scattered savings of the people in the form of premium and then invest it in the form of capital on a long term basis in development projects together with providing protection from various types of risks. Insurance companies stop the flow of capital outside the country. In this manner, insurance companies are playing a vital role in the country as far as the development of insurance business. (Shrestha, 2001).

The insurance industry is a fastest growing industry of Nepal. Since the liberalization of 2046, the government has taken a number of initiations in the area of financial sector reforms including insurance. It is because insurance is also an important part of the overall financial system. The study reveals that net premium collection during 1993/94 to 1997/98 has been increasing and its contribution was also increasing gradually in Gross Domestic Products (GDP) (Vaidya, 2056 BS). 
Insurance Board is an apex regulatory body of insurance companies in Nepal. Under the provisions of Insurance Act and Regulation, Insurance Board has adopted the policy of facilitating the insurance companies to invest in the priority sectors. Moreover, insurance companies have invested in the National Saving Certificate and Government Bonds, fixed deposit, shares and in loan to insurance policy holders. The total investment during 1998/99 to 2002/03 has been increasing rapidly (SEBON, 2007).

The above literature showed that the study of performance of insurance business in overall perspectives has not been conducted yet by any researcher in the context of Nepal. They merely focused on any single aspect of insurance business. Thus, this will be a fruitful study in analysing various aspects of the insurance business in Nepal.

\section{Methodology}

\subsection{Study Horizon and Limitations}

This study focused on the analysis of performance of insurance business in the context of Nepal. In this connection, the study covered all 25 insurance companies -8 life insurance companies, 16 non-life insurance companies and one of both life and non-life insurance companies. The data to be used in this study is the composite details that are recorded and published by Insurance Board of Nepal.

One major limitation is unavailability of quantitative data in standard forms required for systematic study. Another limitation is absence of the use of qualitative information to support descriptive results out in the study. And its span of study period is only for 5 fiscal years i.e. from FY 2062/63 to 2066/67. Thus the findings of the study might be based on the accuracy of the data.

\subsection{Data Collection Techniques}

Basically secondary data has been used in this study. In order to collect the required data, the researcher visited the Insurance Board. Detail updated records on aforementioned study variables have been collected from the Board. Journals, magazines, books and booklets, bulletins, newspapers and other publications were collected and manipulated according to the need of the study. Website of Insurance Board also thoroughly visited to extract necessary and relevant information during the study period.

\subsection{Techniques of Data Analysis}

To meet the objectives of this study various statistical tools like percentage, correlation coefficient, etc. and more as required was used since the study is more analytical in nature. 


\section{Justification of the Study}

Limited studies have been done on insurance business on the whole in Nepalese context. The liberalization process has enhanced the importance of such studies. Growing number of insurance companies, individual policy-holders and market players (agents/surveyors) as well as imperfect insurance market, etc. all made thirst to know the performance of insurance business in Nepal. In this context, this study will be turned out extremely important. It may draw the attention of all existing and prospective policy-holders, government, academicians and researchers as well.

The study of various insurance business indicators such as premium collection and their investments, growth of insurance policies, analysis of investment, etc. are of paramount importance for government as well as policy makers of insurance authority. No systematic study on these aspects thoroughly has been done so far in Nepalese context. This study might contribute to the literature of insurance business in Nepal.

\section{Analysis and Interpretation}

This section of this paper provides a glimpse of Nepalese insurers, number of insurance policies, premium collection and investment for life and non-live insurance, insurance premium and its contribution in GDP and other variables such as number of surveyors, agents, employees and branch offices operating in Nepal. As aforementioned in methodology, various statistical and percentages have been used to measure the performance of insurance business of Nepal.

\subsection{Nepalese Insurers}

Nepalese insurance business showed a rapid growth especially after the enactment of the new Insurance Act, 1992 and Insurance Regulation 1993. At present, there are altogether 25 insurance companies in Nepal. (for detail, refer to Annex). Moreover, the number of insurance offices as branch is 340 in total.

Table 1: Insurance Companies in Nepal

\begin{tabular}{|l|c|c|c|c|c|}
\hline \multicolumn{1}{|c|}{ Ownership } & \multicolumn{3}{|c|}{ Nature of Company } & Total & \multirow{2}{*}{$\begin{array}{c}\text { Percentage } \\
(\%)\end{array}$} \\
\hline & General & Life & Composite & & 4 \\
\hline Government & - & - & 1 & 1 & 72 \\
\hline Private & 13 & 5 & - & 18 & 12 \\
\hline Foreign & 2 & 1 & - & 3 & 12 \\
\hline Joint Venture & 1 & 2 & - & 3 & 100 \\
\hline \multicolumn{1}{|c|}{ Total } & 16 & 8 & 1 & 25 & \\
\hline
\end{tabular}

Source: Insurance Board: A brief profile, 2067. 
Table 1 showed categorically the nature of insurance companies on the basis of their ownership. Rastriya Beema Sansthan, established in 2024 BS, is only one insurance company comprising both life and non-life insurance business under government ownership in Nepal. Private sector insurance companies occupied a big share of 72 percent in Nepalese insurance businesses. Foreign and joint venture insurance companies' carry 12 percent share each in total insurance companies in Nepal.

\subsection{Insurance Policies}

The insurance policy is an agreement which contains all the details related to insurance, the conditions related to the rights, duties and liabilities of both parties viz. insured and insurance company. Basically it contains the name and address of the insured, objectives of the insurance, type of policy, insured amount, term of the insurance, payment of premium, risks to be covered, etc. (Shrestha, 2001). The growth trend of number of insurance policies is shown in Table 2 .

Table 2: Trend of Insurance Policies

\begin{tabular}{|c|c|c|c|}
\hline Fiscal Year & $\begin{array}{c}\text { Life Policies } \\
\text { Growth Rate (\%) }\end{array}$ & $\begin{array}{c}\text { Non-life Policies } \\
\text { Growth Rate (\%) }\end{array}$ & $\begin{array}{c}\text { Total Policies } \\
\text { Growth Rate (\%) }\end{array}$ \\
\hline $2062 / 63$ & 8.20 & -14.64 & 1.84 \\
\hline $2063 / 64$ & 6.06 & 20.59 & 11.61 \\
\hline $2064 / 65$ & 11.43 & 9.35 & 10.57 \\
\hline $2065 / 66$ & 20.51 & 14.13 & 17.91 \\
\hline $2066 / 67^{*}$ & 0.64 & 17.90 & 7.46 \\
\hline
\end{tabular}

*Included insurance policies up to 3rd quarter for FY 2066/67.

\section{Source: website of Insurance Board.}

Table 2 showed the normal growth trends of insurance policies for the study period. The growth rate is highest in FY 2065/66 with 20.51 percent in life insurance and 20.59 percent in non-life insurance whereas it was negative in FY 2062/63 with 14.64 percent. The growth trend as a whole is normally progressive during the study period except in FY 2066/67. The correlation coefficient $r$ between life and non-life policies is 0.91 and is higher than 6 times of its PE. This implies the relationship between growth of life and nonlife insurance policies is significant. Such a progressive growth trend of insurance policies indicates the number of insured has been increasing during the period under study. 


\subsection{Premium Collection and Contribution in GDP}

The collection of premium is the major source of income of insurance companies. The premium may be paid by insured in installments within a specified date or in lump sum. The simple average growth trend of premium collection for both life and non-life insurance and their collective contribution in GDP has been shown in Table 3 .

Table 3: Trend of Premium Collection \& GDP Contributions.

\begin{tabular}{|c|c|c|c|c|}
\hline Fiscal Year & $\begin{array}{c}\text { Life } \\
\text { Premium } \\
\text { Growth Rate (\%) }\end{array}$ & $\begin{array}{c}\text { Non-life } \\
\text { Premium }\end{array}$ & $\begin{array}{c}\text { Total } \\
\text { Premium }\end{array}$ & $\begin{array}{c}\text { GDP } \\
\text { Contribution } \\
\text { Rate (\%) }\end{array}$ \\
\hline $2062 / 63$ & 23.15 & 5.00 & 14.14 & 1.03 \\
\hline $2063 / 64$ & 22.89 & 14.00 & 18.63 & 1.10 \\
\hline $2064 / 65$ & 17.34 & 14.00 & 15.96 & 1.17 \\
\hline $2065 / 66$ & 34.33 & 19.00 & 27.58 & 1.36 \\
\hline $2066 / 67^{*}$ & 37.06 & 48.00 & 41.20 & 1.70 \\
\hline
\end{tabular}

*Estimated figures for FY 2066/67.

Source: website of Insurance Board.

Table 3 showed the highest growth rate of premium collection is 37.06 percent in FY 2066/67 whereas lowest 10.34 percent in FY 2064/65 in case of life insurance. The highest growth was 48 percent in FY 2066/67 for non-life insurance. The growth of premium collection is satisfactory as it has been increasing progressively during the period under study. Similarly, the contribution of premium in GDP has also been continuously increasing over the study period. The correlation coefficient between premium collection between life and non-life insurance is 0.99 which is higher than 6 times of its PE. It implies the relationship in collecting premium in between life and non-life insurance is significant. It shows the collection of premium is satisfactory over the said period

\subsection{Trend of Investments}

Insurance companies are considered as the non-banking financial institutions. However, more of their presence in the economy, the higher the possibility of economic development because they are the institutional investors (Gurung, 2010). As institutional investors, insurance companies may act as principal for their own account, and thereby invest the assets of the insurance company in a wide array of financial instruments i.e. share, 
debenture, etc. in order to produce sufficient income to meet their obligations in the form of promised insurance benefits (SEBON, 2007). They basically invest in corporate securities, government bonds and in commercial and development banks as fixed deposit. The growth trend of investment for both life and non-life insurance has been shown in Table 4.

Table 4: Growth Trend of Investments

\begin{tabular}{|c|c|c|c|}
\hline Fiscal Year & $\begin{array}{c}\text { Life } \\
\text { Growth Rate (\%) }\end{array}$ & $\begin{array}{c}\text { Non-life } \\
\text { Growth Rate (\%) }\end{array}$ & $\begin{array}{c}\text { Total } \\
\text { Growth Rate (\%) }\end{array}$ \\
\hline $2062 / 63$ & 28.82 & 5.94 & 24.14 \\
\hline $2063 / 64$ & 21.03 & 7.37 & 18.65 \\
\hline $2064 / 65$ & 10.61 & 21.34 & 12.30 \\
\hline $2065 / 66$ & 30.30 & 19.72 & 28.50 \\
\hline $2066 / 67^{*}$ & 12.91 & 18.36 & 13.78 \\
\hline
\end{tabular}

*Estimated figures for FY 2066/67.

Source: website of Insurance Board.

Table 4 showed the erratic trend of investment during the study period. Investment is lowest in FY 2064/65 with 10.61 percent and highest 30.30 percent in 2065/66 for life insurance. The investment of non-life insurance companies has been also increasing in the first three fiscal years then downturned slowly in the subsequent FYs of the study period. Similarly, the overall growth rate of investment has also been fluctuating positively. The correlation coefficient $r$ of investment between life and non-life insurance is 0.98 which is higher than the 6 times of its PE. This implies that the presence of investment of insurance companies is satisfactory during the study period.

\subsection{Trends Between Premium Collection and Investment}

The major source of income of insurance companies is collection of premium from the policyholders. As institutional investors, they invest such collection in different fields as stated earlier. The growth trends and the interrelationship between premium collection and investment has been shown in Table 5 . 
Table 5: Trend of Premium Collection and Investment

\begin{tabular}{|c|c|c|}
\hline Fiscal Year & $\begin{array}{c}\text { Premium Collection } \\
\text { Growth Rate (\%) }\end{array}$ & $\begin{array}{c}\text { Investment } \\
\text { Growth Rate (\%) }\end{array}$ \\
\hline $2062 / 63$ & 14.14 & 24.14 \\
\hline $2063 / 64$ & 18.63 & 18.65 \\
\hline $2064 / 65$ & 15.96 & 12.30 \\
\hline $2065 / 66$ & 27.58 & 28.50 \\
\hline $2066 / 67^{*}$ & 41.20 & 13.78 \\
\hline
\end{tabular}

*Estimated figures for FY 2066/67.

\section{Source: website of Insurance Board.}

Table 5 shows that the total premium collection has been progressively increasing except in FY 2064/65 with only 15.96 percent. But the growth rate of total investment is fluctuating positively over the period under study. The correlation coefficient $r$ between total premium collection and total investment is 0.97 and it is higher than 6 times of its PE. This indicates that the relationship between premium collection and investment is positive and significant. This implies that the overall performance of premium collection and their investment is increasing during the study period.

\subsection{Others}

At the end of FY 2066/67, the number of insurance surveyors is 138 but it was 152 in FY 2063/64. Likewise, the number of insurance agent is 66,799 in Nepal. They are sometimes also called insurance brokers. The number of employees working in insurance companies is 2581 till the end of FY 2066/67. These facts indicate that the insurance business in Nepal is normally small in size though it is developing gradually.

\section{Conclusion}

Insurance is an agreement between insured and the insurer. As per agreement, the insured pays premium to the insurer in installments while the insurer promises to offer financial security from the risks involved. The insurer, then, invests in industrial and financial institutions as per the provisions made in investment guidelines of Insurance Board.

The study shows that the insurance policies for both life and non-life insurance are 
progressively increasing over the study period in Nepal. Similarly, the premium collection and its contribution in GDP are also increasing year after year. Likewise, the investment of life and non-life insurance companies is also increasing positively as the relationship between life and non-life insurance is significant during the study period. The growth trend of total premium collection and total investment are increasing and they have significant relationship with each other. These all facts reveal that the performance of Nepalese insurance companies is satisfactory. More specifically, the performance of both life and non-life insurance companies in terms of premium collection and investment is satisfactory in Nepal.

\section{REFERENCES}

Gurung, J.B. (2010). Banking in Nepal: Growth and analysis of performance. Pokhara Management Review, 47-58.

Insurance Board: A brief profile. (n.d.). Kathmandu: Insurance Board.

Shrestha, H. P. (2001). Business organization and office management. Kathmandu: Ratna Pustak Bhandar.

Singh, H. B. (2009). Banking and insurance (4 ${ }^{\text {th }}$ ed). Kathmandu: Asia Publications (P) Ltd.

Securities Board of Nepal. (2007). Institutional investment in Nepalese securities market. SEBON Journal, 3 (1): 80-94.

Thapa, K., \& Neupane, K. D. (2065). Banking and insurance. Kathamandu: Asmita Books.

Vaidya, S. (2056). Financial market and institutions. Kathmandu: Taleju Prakashan.

www.bsib.org 


\section{Annex}

\section{List of Insurers or Insurance Companies}

\begin{tabular}{|c|c|c|c|}
\hline S.N. & Company & Category & Address and Phone \\
\hline 1. & Nepal Insurance Company Ltd. & Non-life & Kamaladi, Kathmandu, 4245565 \\
\hline 2. & The Oriental Insurance Company Ltd. & Non-life & Kantipath, Kathamandu, 4221448 \\
\hline 3. & Rastriya Beema Sansthan & $\begin{array}{l}\text { Life \& } \\
\text { Non-life }\end{array}$ & Ramshahapath,Kathmandu , 4262565 \\
\hline 4. & ty Ltd. & $\mathrm{fe}$ & 4250710 \\
\hline 5. & National Life Insurance Company Ltd. & Life & Naxal, Kathmandu, 4414799 \\
\hline 6. & Himalayan General Insurance Company Ltd. & Non-life & Babarmahal,Kathmandu, 4231788 \\
\hline 7. & United Insurance Company (Nepal) Ltd. & -life & Darbarmarg,Kathmandu, 4220492 \\
\hline 8. & Premier Insurance Company (Nepal) Ltd. & Non-life & Tripureshwor, $\mathrm{Ka}$ \\
\hline 9. & Everest Insurance Company Ltd. & Non-life & Hattisar, Kathmandu, 4444717 \\
\hline 10. & rance Ltd. & life & Putalisadak,Kat \\
\hline 11. & Sagarmatha Insuranc & life & Naxal, K \\
\hline 12. & Alliance Insurance Company Ltd. & ife & Tinkune, Kathmandu, 4499226 \\
\hline 13. & N.B. Insurance Company Ltd. & -life & Kamaladi, Kathmandu, 4442457 \\
\hline 14. & Nepal Life Insurance Company Ltd. & $\mathrm{L}$ & $\mathrm{u}, 4223440$ \\
\hline 15. & Nepal) Ltd. & $\mathrm{L}$ & KathmanduPlaza, Ka \\
\hline 16. & $\begin{array}{l}\text { American Life Insurance Company } \\
\text { (ALICO) Ltd. }\end{array}$ & $\mathrm{Li}$ & $\mathrm{Pu}$ \\
\hline 17. & Prudential Insurance Company Ltd. & life & Putalisadak, Kathmandu, 4212940 \\
\hline 18. & Shikhar Insurance Company Ltd. & life & Thapathali, Kathmandu, 4246101 \\
\hline 19. & Lumbini General Insurance Company Ltd. & -life & Thamel, Kathme \\
\hline 20. & NLG Insurance Company Ltd. & -life & Panipokhari, Kathm \\
\hline 21. & Siddhartha Insurance Ltd. & Non-life & Tripureshwor, Kathmandu, 4257766 \\
\hline 22. & Asian Life Insurance Company Ltd. & Life & Dillibazar, Kathmandu, 4440986 \\
\hline 23. & Surya Life Insurance Company Ltd. & Life & Gairidhara, Kathmandu, 4004028 \\
\hline 24. & Gurans Life Insurance Company Ltd. & Life & Lalkolanimarg, Kathmandu, 4441521 \\
\hline 25. & Prime Life Insurance Company Ltd. & $\mathrm{Li}$ & Hattisar, Kathmandu, 4441778 \\
\hline
\end{tabular}

Source: Insurance Board, 2067 